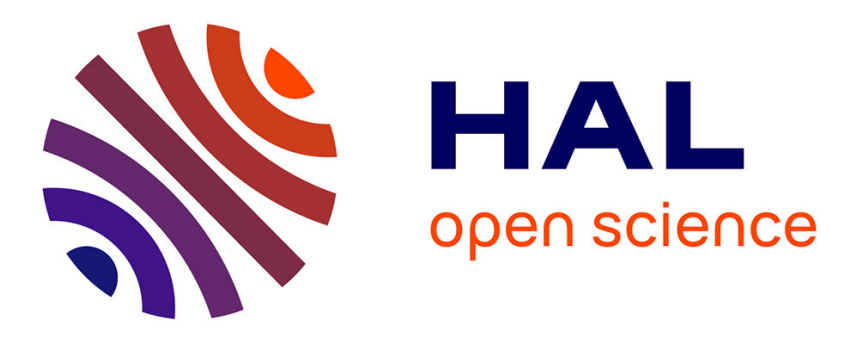

\title{
Effects of region, soil, land use, and terrain type on fuelwood properties of five tree/shrub species in the Sahelian and Sudanian ecozones of Mali
}

Sotelo Montes, John Weber, Dimas Silva, Andrade, Graciela Muñiz, Rosilei Garcia, Kalinganire

\section{To cite this version:}

Sotelo Montes, John Weber, Dimas Silva, Andrade, Graciela Muñiz, et al.. Effects of region, soil, land use, and terrain type on fuelwood properties of five tree/shrub species in the Sahelian and Sudanian ecozones of Mali. Annals of Forest Science, 2012, 69 (6), pp.747-756. 10.1007/s13595-012-0195-2 . hal-00930845

\section{HAL Id: hal-00930845 https://hal.science/hal-00930845}

Submitted on 1 Jan 2012

HAL is a multi-disciplinary open access archive for the deposit and dissemination of scientific research documents, whether they are published or not. The documents may come from teaching and research institutions in France or abroad, or from public or private research centers.
L'archive ouverte pluridisciplinaire HAL, est destinée au dépôt et à la diffusion de documents scientifiques de niveau recherche, publiés ou non, émanant des établissements d'enseignement et de recherche français ou étrangers, des laboratoires publics ou privés. 


\title{
Effects of region, soil, land use, and terrain type on fuelwood properties of five tree/shrub species in the Sahelian and Sudanian ecozones of Mali
}

\author{
Carmen Sotelo Montes • John C. Weber • \\ Dimas A. Silva • Clarice Andrade • \\ Graciela I. B. Muñiz • Rosilei A. Garcia • \\ Antoine Kalinganire
}

Received: 27 October 2011 / Accepted: 11 February 2012/Published online: 7 March 2012

(C) INRA / Springer-Verlag France 2012

\begin{abstract}
- Context There is little information about inter- and intraspecific variation in fuelwood properties of trees/shrubs in West Africa.

- Aims We studied variation in fuelwood properties of Balanites aegyptiaca, Combretum glutinosum, Guiera senegalensis, Piliostigma reticulatum, and Zizyphus mauritiana in the Sahelian and Sudanian ecozones of Mali.

- Methods Trees were sampled on different soil (sandy, sandy/loam, or rocky), land use (parkland agroforest or woodland), and terrain (flat, temporarily flooded, or hill
\end{abstract}

\section{Handling Editor: Shuqing Zhao}

Contribution of the co-authors Carmen Sotelo Montes: project design, field work, sample preparation, data collection (geographical coordinates, age, density), data analysis, writing the paper. John C. Weber: project design, field work, supervision of data analysis, writing the paper. Dimas A. Silva, Clarice Andrade, Graciela I.B. Muñiz: data collection (volatile matter, fixed carbon, ash content, moisture content, gross and net calorific values). Rosilei A. Garcia: coordination of work with universities in Brazil, reviewing the paper. Antoine Kalinganire: reviewing the paper

C. Sotelo Montes $(\bowtie) \cdot$ J. C. Weber $\cdot$ A. Kalinganire

World Agroforestry Centre (ICRAF), Sahel Office,

B. P. E 5118 Bamako, Mali

e-mail: c.sotelo@cgiar.org

J. C. Weber

e-mail: johncrweber@aol.com

A. Kalinganire

e-mail: a.kalinganire@cgiar.org

D. A. Silva $\cdot$ C. Andrade • G. I. B. Muñiz

Universidade Federal do Paraná,

Av. Lothário Meissner, 900,

CEP: 80270-170 Curitiba, Brazil slope) types in five regions extending from the drier eastern to the more humid western parts of Mali. Basic density, volatile matter, fixed carbon, ash content, moisture content, gross calorific value, and fuel value index were measured for each tree and adjusted for tree age.

- Results All fuelwood properties differed significantly among species, but there were significant species by region interactions. Most fuelwood properties of four species differed significantly among regions. Soil and/or land use type had significant effects on a few fuelwood properties of four species.
D. A. Silva

e-mail: dimass@ufpr.br

C. Andrade

e-mail: claricedeandrade2@gmail.com

G. I. B. Muñiz

e-mail: gbmunize@ufpr.br

R. A. Garcia

Instituto de Florestas, Departamento de Produtos Florestais,

Universidade Federal Rural do Rio de Janeiro,

BR 465, km 07, 23890-000, Seropédica, Rio de Janeiro, Brazil

e-mail: rosileigar@ufrrj.br 
- Conclusion In general, fuelwood production is recommended in all regions for $G$. senegalensis, in drier regions for B. aegyptiaca and C. glutinosum, in more humid regions for $Z$. mauritiana, and on rocky soils for all species. Fuelwood production of $P$. reticulatum is not recommended.

Keywords Basic density. Volatile matter. Fixed carbon . Ash content $\cdot$ Moisture content $\cdot$ Gross calorific value

\section{Introduction}

Rural communities in the Sahelian and Sudanian ecozones of West Africa use many native tree species for fuelwood (Faye et al. 2011) and demand for fuelwood is increasing (FAO 2011). Environmental conditions can directly or indirectly affect fuelwood properties. For example, ash content of wood may be greater in sites where there is more available calcium and potassium in the soil (Sarmiento et al. 1985); and wood density may be correlated with tree growth rate, which in turn is affected by rainfall, soil fertility, etc. (e.g., Sotelo Montes et al. 2006). There is very little published information about variation in fuelwood properties in natural populations, and this information is needed in order to target species and environments for production of higher quality fuelwood.

Several properties should be considered when assessing the value of wood for fuel. Gross and net calorific values are the amounts of energy per unit mass that are released from the complete combustion of oven-dried and air-dried wood samples, respectively, so wood with high gross and net calorific values is clearly desirable (Nirmal Kumar et al. 2011). Denser wood has more energy per unit volume and burns more slowly (Fuwape and Akindele 1997). High moisture and ash contents reduce gross calorific value because energy is used to evaporate the water and ash is the non-combustible mineral residue in the wood (Shanavas and Mohan Kumar 2003). Volatile matter is released as combustible and non-combustible gasses when the wood is burned; and fixed carbon is the mass, excluding ash and moisture content, remaining after the volatile matter is released (McKendry 2002). Wood with higher volatile matter ignites more rapidly and produces more heat during combustion but it may also produce more smoke, and wood with higher fixed carbon burns longer (Fuwape and Akindele 1997; Kataki and Konwer 2002). Several fuel value indices have been used to quantify the overall quality of fuelwood from different species: the most commonly used index in recent years adjusts gross calorific value for the density, ash, and moisture contents of the wood (e.g., Sotelo Montes et al. 2011).

In this paper, we discuss variation in fuelwood properties of five tree/shrub species in the Sahelian and Sudanian ecozones of Mali. The Sahel is a semi-arid transitional ecozone between the more humid Sudanian ecozone to the south and the Sahara
Desert to the north, so there are steep rainfall gradients with latitude and also with longitude. The species [Balanites aegyptiaca (L.) Delile (Balanitaceae), Combretum glutinosum Perr. ex DC. (Combretaceae), Guiera senegalensis J.F. Gmel. (Combretaceae), Piliostigma reticulatum (DC.) Hochst. (Caesalpiniaceae), and Zizyphus mauritiana Lam. (Rhamnaceae)] are used for fuelwood and also provide additional products and environmental services for rural communities (Faye et al. 2011). They tolerate and/or avoid drought stress during the long dry period (typically from October to June), and are common in woodlands and "parkland" agroforests, which rural communities manage for the production of food crops, tree products, and livestock. B. aegyptiaca and Z. mauritiana are distributed from the Sahelian to the northern part of the Sudanian ecozone, and C. glutinosum, G. senegalensis, and $P$. reticulatum are distributed from the Sahelian to the southern part of the Sudanian ecozone (Le Houérou 1980). B. aegyptiaca is an evergreen, drought-tolerant tree that produces a deep taproot and grows very slowly above ground (Hall and Walker 1991). C. glutinosum is also an evergreen tree, with dense foliage in the crown, but it grows only near available water sources and has active photosynthesis only during the rainy season in the drier north (Berger et al. 1996). G. senegalensis is a shrub that produces roots extending at least $4 \mathrm{~m}$ in depth, grows quickly above ground and adjusts its leaf surface area to available soil water, thereby allowing active photosynthesis during part of the dry season (Seghieri et al. 2005; Kizito et al. 2006). $P$. reticulatum is a semi-evergreen, leguminous shrub that produces roots extending at least $3 \mathrm{~m}$ in depth, does not fix nitrogen, grows well in temporarily flooded sites, and has adventitious shoots that tend to grow at oblique angles rather than vertically, thereby creating a microhabitat favorable for growth (Wezel et al. 2000; Kizito et al. 2006). Z. mauritiana is a relatively fast growing tree that produces deep roots, avoids drought by shedding its leaves during the dry season and is common in woodlands and along temporary streams (Berger et al. 1996; Clifford et al. 1998).

The major objective of this research was to determine if fuelwood properties (basic density, volatile matter, fixed carbon, ash content, moisture content, gross calorific value, fuelwood value index) of the species differ among regions, soil types, land use types, and terrain types in Mali. Recommendations are provided regarding the species and sites to target for fuelwood production, and seed sources to use for establishing new fuelwood plantations.

\section{Materials and methods}

2.1 Study regions, tree sampling, and site variables

B. aegyptiaca, C. glutinosum, G. senegalensis, P. reticulatum, and $Z$. mauritiana were sampled in parklands and 


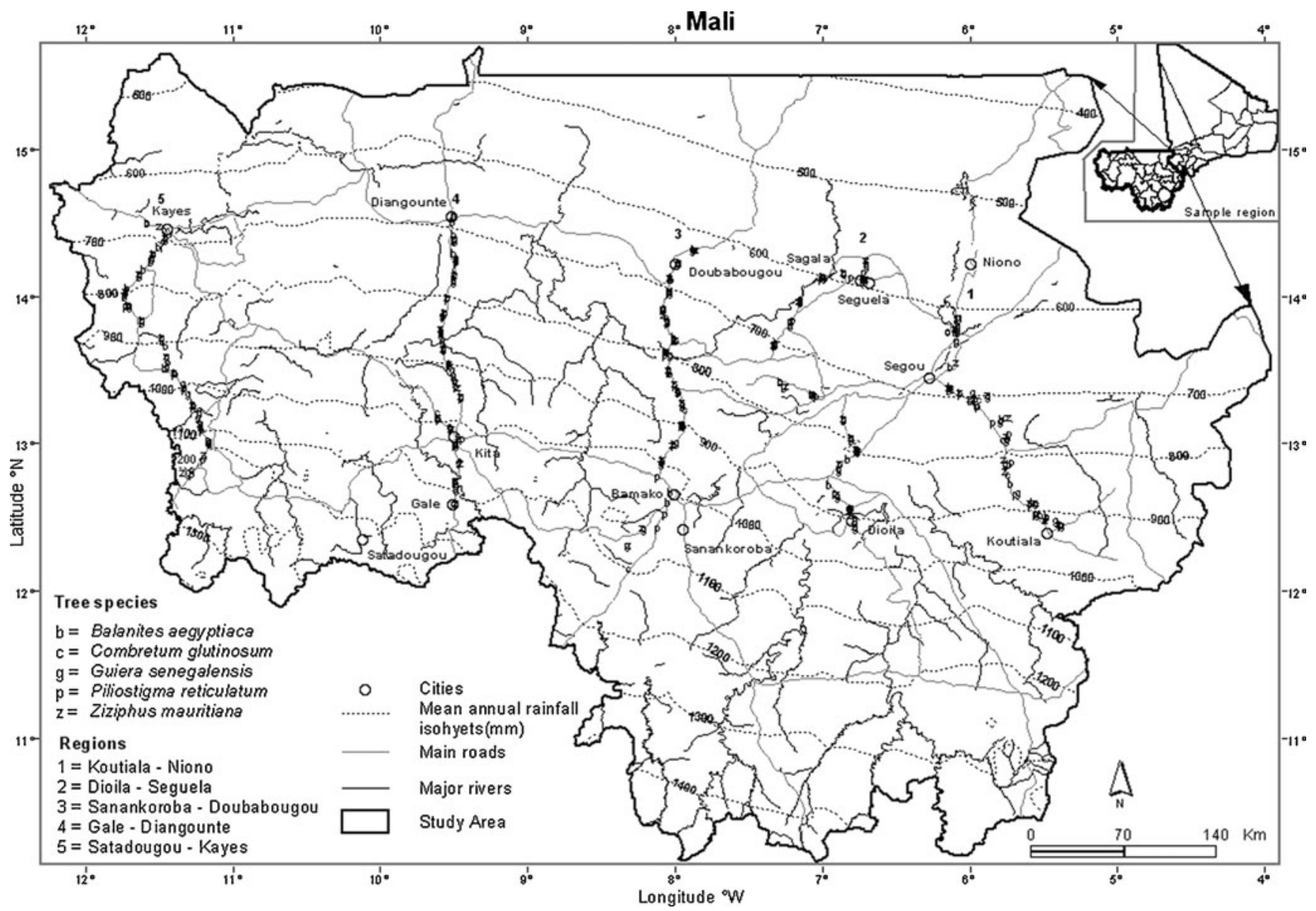

Fig. 1 Geographic location of five tree/shrub species sampled in five regions in Mali, and mean annual rainfall isohyets across the sample regions

woodlands in five regions, extending from southeastern to southwestern Mali (Fig. 1), at the end of the dry season in 2009. For each species, 15-16 trees were sampled roughly along a latitudinal transect in each region, with a minimum distance of $10 \mathrm{~km}$ between trees. Trees were selected if they were produced by natural regeneration; the stem was not a coppice shoot, and was undamaged, growing relatively upright and within a predetermined diameter class (4-12 $\mathrm{cm}$ at $30 \mathrm{~cm}$ above ground). Tree stems in this diameter class are typically cut for firewood. Information about tree age, elevation, annual rainfall and sample sizes in each region is given in Table 1.

Three site variables were visually assessed for each tree: soil type (primarily sand, sand/loam mixture or primarily rocks including laterite), land use type (parkland agroforest or woodland), and terrain type (flat, temporarily flooded, or hill slope). Detailed information about the species composition, etc. of parkland agroforests and woodlands was not recorded. Latitude, longitude, and elevation of each tree were obtained using a GPS receiver, and mean annual rainfall ( $\mathrm{mm})$ was obtained from the WorldClim database, described elsewhere (Hijmans et al. 2005), using the trees' geographical coordinates.

\subsection{Wood samples and fuelwood variables}

The stem of each tree was cut at 30 and $60 \mathrm{~cm}$ above ground in the field. The north- and south-facing sides were labeled on the bark and cut surfaces. The bark was removed from each stem sample in a laboratory in Mali, lines were drawn along the north- and south-facing sides of the wood, and the samples were then air-dried for 2 months.

Two disks, without nodes or other defects, were cut from the lower part of the stem sample and used for determination of wood density and tree age. The disks were air-dried for 1 month to obtain equilibrium moisture content (EMC) prior to measurements. Basic density (BDen) of one disk (2 cm thick, generally at $31-33 \mathrm{~cm}$ above ground) was measured in $\mathrm{kg} \mathrm{m}^{-3}$ using the water displacement method (ASTM 1997). The number of annual rings was counted on the second disk $(1 \mathrm{~cm}$ thick, generally at $33-34 \mathrm{~cm}$ above ground) and used as an estimate of tree age. As others have demonstrated, annual rings can be visually distinguished in both deciduous and evergreen tree species in semi-arid zones and used to estimate tree age if there is a distinct dry season to induce cambial dormancy and trigger 
Table 1 Estimated age, elevation, and mean annual rainfall of five tree/shrub species sampled in five regions in Mali

\begin{tabular}{|c|c|c|c|c|c|c|c|c|c|c|c|}
\hline \multirow{2}{*}{$\begin{array}{l}\text { Species }^{\mathrm{a}} \\
\text { Variable }^{\mathrm{b}}\end{array}$} & \multirow[t]{2}{*}{ Mean } & \multicolumn{5}{|c|}{ Mean by region ${ }^{\mathrm{c}}$} & \multicolumn{5}{|c|}{ Minimum-maximum by region $^{\mathrm{c}}$} \\
\hline & & $\mathrm{R} 1$ & $\mathrm{R} 2$ & R3 & R4 & $\mathrm{R} 5$ & $\mathrm{R} 1$ & $\mathrm{R} 2$ & R3 & R4 & R5 \\
\hline \multicolumn{12}{|l|}{$\mathrm{Ba}$} \\
\hline Age & 5.2 & 5.3 & 5.6 & 5.4 & 4.6 & 4.9 & $3-7$ & $4-7$ & $3-8$ & $3-6$ & $3-7$ \\
\hline Elevation & 280 & 294 & 307 & 385 & 297 & 120 & $260-351$ & $275-364$ & $294-462$ & $217-352$ & $35-209$ \\
\hline Rainfall & 791 & 765 & 730 & 825 & 815 & 815 & $614-923$ & $577-893$ & $626-1,030$ & $684-1,020$ & $669-1,045$ \\
\hline Sample size & 79 & 15 & 16 & 16 & 16 & 16 & & & & & \\
\hline \multicolumn{12}{|l|}{$\mathrm{Cg}$} \\
\hline Age & 5.9 & 5.2 & 5.9 & 6.2 & 6.0 & 6.3 & $4-8$ & $5-8$ & $5-9$ & $5-7$ & $4-9$ \\
\hline Elevation & 282 & 303 & 302 & 386 & 298 & 130 & $254-365$ & $250-341$ & $280-468$ & $235-355$ & $36-200$ \\
\hline Rainfall & 831 & 754 & 733 & 827 & 916 & 925 & $623-923$ & $571-914$ & $631-1,094$ & $721-1,130$ & $669-1,207$ \\
\hline Sample size & 79 & 16 & 16 & 15 & 16 & 16 & & & & & \\
\hline \multicolumn{12}{|l|}{ Gs } \\
\hline Age & 6.2 & 5.0 & 7.0 & 6.3 & 6.3 & 6.6 & $3-8$ & $5-9$ & $4-9$ & $4-8$ & $5-9$ \\
\hline Elevation & 286 & 297 & 312 & 393 & 293 & 134 & $257-350$ & $284-363$ & $263-463$ & $193-357$ & $50-201$ \\
\hline Rainfall & 838 & 765 & 734 & 830 & 923 & 937 & $607-923$ & 577-914 & $631-1,072$ & $711-1,130$ & $687-1,205$ \\
\hline Sample size & 79 & 15 & 16 & 16 & 16 & 16 & & & & & \\
\hline \multicolumn{12}{|l|}{$\operatorname{Pr}$} \\
\hline Age & 6.4 & 6.3 & 7.1 & 6.4 & 6.0 & 6.4 & $5-9$ & $5-11$ & $4-8$ & $5-7$ & $5-9$ \\
\hline Elevation & 286 & 298 & 314 & 386 & 295 & 136 & $277-356$ & 279-380 & $281-438$ & $233-361$ & 54-214 \\
\hline Rainfall & 838 & 764 & 732 & 826 & 915 & 950 & 609-923 & $585-890$ & $626-1,044$ & $711-1,088$ & $687-1,207$ \\
\hline Sample size & 79 & 15 & 16 & 16 & 16 & 16 & & & & & \\
\hline \multicolumn{12}{|l|}{$\mathrm{Zm}$} \\
\hline Age & 5.8 & 5.3 & 5.8 & 5.8 & 5.7 & 6.4 & $4-7$ & 4-9 & $4-8$ & $4-8$ & $5-8$ \\
\hline Elevation & 285 & 302 & 308 & 393 & 302 & 122 & $250-352$ & $273-362$ & $292-450$ & $246-355$ & $43-205$ \\
\hline Rainfall & 835 & 764 & 735 & 829 & 919 & 924 & $614-927$ & $571-942$ & $626-1,072$ & $711-1,130$ & $677-1,208$ \\
\hline Sample size & 79 & 15 & 16 & 16 & 16 & 16 & & & & & \\
\hline
\end{tabular}

${ }^{a}$ Species: Ba Balanites aegyptiaca, Cg Combretum glutinosum, Gs Guiera senegalensis, Pr Piliostigma reticulatum, Zm Ziziphus mauritiana

${ }^{\mathrm{b}}$ Variable: Age=estimated age (years), Elevation=estimated elevation $(\mathrm{m})$, Rainfall=estimated mean annual rainfall $(\mathrm{mm})$, and Sample size $=$ number of sampled trees/shrubs

${ }^{\mathrm{c}} \mathrm{R} 1$ to $\mathrm{R} 5=$ regions 1 to 5 see Fig. 1

formation of growth boundaries (Gourlay 1995; Tarhule and Hughes 2002; Gebrekirstos et al. 2008); and there is a distinct dry season of approximately 8 months following the rainy season in Mali (Hiernaux and Le Houérou 2006). The lower surface of the second disk was sanded so that the annual rings were clearly visible, and the four cardinal directions (i.e., north, east, south, and west) were labeled on the surface. A digital image of the surface was produced with a scanner. A grid (mm) was overlaid on the image and the annual rings were marked along the four cardinal directions using Adobe ${ }^{\circledR}$ Photoshop CS4 version 11 software. The number of rings was then counted.

Sawdust was prepared from the remaining part of the airdried stem samples (generally between 36 and $40 \mathrm{~cm}$ above ground) and used to measure other fuelwood properties at the Laboratory of Energy of Biomass of the Universidade Federal do Paraná in Brazil. The sawdust samples were stored under controlled conditions $(60 \%$ relative humidity, $20^{\circ} \mathrm{C}$ ) for 1 month to attain EMC prior to measurements. Gross calorific value is the total energy available from an oven-dry sample, and net calorific value is the total energy available from an air-dry sample: these are also known as the upper and lower heating values, respectively. Following procedures described elsewhere (ABNT 1984), percent moisture content (MC) was determined from a small sample $(0.5 \mathrm{~g})$ of sawdust, and then the oven-dry sample of sawdust was used to determine gross calorific value (GCV) in $\mathrm{MJ} \mathrm{kg}^{-1}$. Net calorific value (Net CV) was calculated from GCV: Net $\mathrm{CV}$ equals GCV minus the energy needed to evaporate the water $\left(1.36 \mathrm{MJ} \mathrm{kg}^{-1}\right)$. Gross calorific value per cubic meter $\left(\mathrm{GCVm}^{3}\right)$ was calculated as the product of BDen and GCV. The percent contents of volatile matter (Vol), fixed carbon (Carb), and ash (Ash) were determined from the mean of two small air-dried samples of sawdust (each about $4 \mathrm{~g}$ ): Vol and 
Ash were measured, and Carb was calculated as $100 \%-$ VolAsh (ABNT 1986). The fuel value index (FVI) was calculated using the following formula: $\mathrm{FVI}=[(\mathrm{BDen})(\mathrm{Net} \mathrm{CV})] /$ [(Ash) (MC)] (Sotelo Montes et al. 2011).

\subsection{Data analysis}

The SAS ${ }^{\circledR}$ statistical package (SAS Institute Inc. 2004) was used for all analyses, and the significance level was $\alpha \leq 0.05$ for all tests. BDen, Vol, Carb, Ash, MC, GCV, GCVm ${ }^{3}$, and FVI were analyzed. Data transformations were not necessary as the variables exhibited normal distributions (UNIVARIATE procedure).

Values for all fuelwood variables were adjusted for differences in tree age. In a preliminary analysis of covariance (MIXED procedure, restricted maximum likelihood estimation method), the effects of age (covariate), region, and the age by region interaction were tested for each variable of each species. The effect of age was generally not significant, but the age by region interaction was significant in many cases, indicating that the effect of age depended on the region. Therefore, the analysis of covariance was repeated by region for each species, and data were adjusted using the following formula:

$\mathrm{Y}_{\text {age-adjusted }}=\mathrm{Y}_{\text {unadjusted }}-\left(\right.$ Beta $\left._{\text {age-region }}\right) *\left(\right.$ Age $\left._{\text {tree }}-\mathrm{Age}_{\text {species }}\right)$,

where $Y_{\text {age-adjusted }}=$ the value of the variable adjusted for tree age, $Y_{\text {unadjusted }}=$ the value of the variable not adjusted for tree age, Beta $_{\text {age-region }}=$ the effect of age on the variable within the region (i.e., the covariate parameter estimate), $\mathrm{Age}_{\text {tree }}=$ estimated age of the tree, and $\mathrm{Age}_{\text {species }}=$ mean age of all trees of the species.

Mean age of the sampled trees (with minimum and maximum in parentheses) was 5.2 (3-8), 5.8 (4-9), 5.9 (3-9), 6.2 (4-11), and 6.4 (4-9)years, respectively for B. aegyptiaca, Z. mauritiana, C. glutinosum, G. senegalensis, and P. reticulatum. The differences in mean age were small but statistically significant in some cases (B. aegyptiaca $<$ other species, $Z$. mauritiana and $C$. glutinosum $<P$. reticulatum; Tukey test $P<0.05$ ), but that would have little if any effect on interspecific differences in fuelwood properties based on previous research (e.g., Lemenih and Bekele 2004; Kumar et al. 2010).

Analysis of variance (ANOVA, MIXED procedure, restricted maximum likelihood estimation method) was used to determine if fuelwood variables differed significantly among species, regions, and site variables. Two ANOVA models were used to test differences among and within species. The model among species included five main effects (species, region, soil type, land use type, terrain type) and the two-way interactions between species and the other main effects (all fixed factors). The model within species included four main effects (region, soil type, land use type, terrain type). Interactions between regions and site variables were not tested because there were not enough observations for some site variables in some regions. Least-squares means were compared using the Tukey HSD (honestly significant difference) test. The Tukey test controls the experiment-wise error so it is very conservative: if the $\mathrm{F}$ test is barely significant, then the Tukey test may not detect any significant difference among the means.

Pearson correlation coefficients (Corr procedure) were used to investigate linear relationships among fuelwood properties of the trees for each species.

\section{Results}

\subsection{Differences in fuelwood properties among species}

All fuelwood variables differed significantly among species (Table 2). There were no significant interactions between species and site variables. However, the species by region interaction was significant for five variables [Vol, MC, GCV $(P<0.001)$; Ash $(P<0.01)$; Carb, FVI $(P<0.05)$ ], indicating that rankings of some species changed in some regions. Differences due to regions and site variables are discussed in the Sections 3.2 and 3.3, respectively.

In general, G. senegalensis had better fuelwood properties than the other species (Table 2). Its FVI was high because it had the highest BDen and GCV, the lowest Ash, and moderate MC. It also had the highest $\mathrm{GCVm}^{3}$ because this is a function of BDen and GCV, and the highest FVI because this is a function of BDen, Net CV, Ash, and MC. P. reticulatum had the least desirable fuelwood properties (low BDen and GCV, high Ash and MC).

Judging from the coefficients of variation, there was relatively little variation in BDen, Vol, Carb, MC, GCV, and $\mathrm{GCVm}^{3}$ (Table 2). Ash and FVI had very large coefficients of variation compared with the other fuelwood properties. The coefficients of variation were generally greater for $C$. glutinosum than for the other species.

\subsection{Differences in fuelwood properties among regions}

Mean annual rainfall was lower in the eastern and higher in the western regions (Table 1). The range in mean annual rainfall among sample locations was lower for B. aegyptiaca (575$1,045 \mathrm{~mm}$ ) than for the other species (about 575-1,205 mm).

Regional differences were significant for at least four of the eight fuelwood properties of B. aegyptiaca, G. senegalensis, $P$. reticulatum, and $Z$. mauritiana (Table 3 ). However, most fuelwood properties of $C$. glutinosum did not differ significantly among regions. BDen did not differ significantly among regions for any species.

Fuelwood properties were better in some regions for some species and in other regions for other species (Table 3). 
Table 2 Means and coefficients of variation of fuelwood properties of five tree/shrub species in Mali

\begin{tabular}{|c|c|c|c|c|c|c|c|c|c|c|c|}
\hline \multirow[t]{2}{*}{ Variable $^{\mathrm{a}}$} & \multirow[t]{2}{*}{$P^{\mathrm{b}}$} & \multicolumn{5}{|c|}{ Means for species ${ }^{c}$} & \multicolumn{5}{|c|}{ Coefficient of variation $(\%)$} \\
\hline & & $\mathrm{Ba}$ & $\mathrm{Cg}$ & Gs & $\operatorname{Pr}$ & $\mathrm{Zm}$ & $\mathrm{Ba}$ & $\mathrm{Cg}$ & Gs & $\operatorname{Pr}$ & $\mathrm{Zm}$ \\
\hline BDen & $* * *$ & $615 \mathrm{c}$ & $666 \mathrm{~d}$ & $673 d$ & $530 \mathrm{a}$ & $569 \mathrm{~b}$ & 5.7 & 7.7 & 5.1 & 6.9 & 7.7 \\
\hline Vol & $* * *$ & $80.20 \mathrm{~b}$ & $79.95 b$ & $79.90 \mathrm{~b}$ & $78.45 \mathrm{a}$ & $80.70 \mathrm{~b}$ & 1.5 & 2.0 & 1.0 & 1.5 & 1.6 \\
\hline Carb & $* * *$ & $18.55 \mathrm{ab}$ & $18.84 \mathrm{abc}$ & $19.47 \mathrm{bc}$ & $19.63 \mathrm{c}$ & $18.18 \mathrm{a}$ & 5.2 & 8.4 & 4.1 & 5.0 & 6.6 \\
\hline Ash & $* * *$ & $1.25 \mathrm{~b}$ & $1.22 \mathrm{~b}$ & $0.64 \mathrm{a}$ & $1.93 \mathrm{c}$ & $1.12 \mathrm{~b}$ & 27.5 & 39.7 & 32.7 & 28.4 & 32.4 \\
\hline $\mathrm{MC}$ & $* *$ & $11.14 \mathrm{ab}$ & $10.78 \mathrm{a}$ & $11.18 \mathrm{ab}$ & $11.74 b$ & $10.80 \mathrm{a}$ & 11.4 & 12.8 & 12.5 & 9.5 & 10.9 \\
\hline GCV & $* * *$ & $19.14 \mathrm{ab}$ & $19.08 \mathrm{ab}$ & $19.93 \mathrm{c}$ & $19.03 \mathrm{a}$ & $19.40 \mathrm{~b}$ & 2.2 & 2.0 & 1.3 & 1.9 & 1.8 \\
\hline $\mathrm{GCVm}^{3}$ & $* * *$ & $11,783 b$ & $12,707 \mathrm{c}$ & $13,416 \mathrm{c}$ & $10,076 a$ & $11,036 \mathrm{~b}$ & 6.3 & 8.1 & 5.1 & 7.0 & 7.8 \\
\hline FVI & $* * *$ & $886 \mathrm{~b}$ & $1,020 \mathrm{~b}$ & $2,081 \mathrm{c}$ & $477 \mathrm{a}$ & $918 b$ & 38.1 & 42.8 & 30.2 & 33.1 & 36.8 \\
\hline
\end{tabular}

${ }^{\text {a }}$ Variable: BDen=wood basic density $\left(\mathrm{kg} \mathrm{m}^{-3}\right)$; Vol, Carb, Ash, and $\mathrm{MC}=$ volatile matter, fixed carbon, ash, and moisture, respectively, of wood (\%); GCV and $\mathrm{GCVm}^{3}=$ gross calorific value of wood $\left(\mathrm{MJ} \mathrm{kg}^{-1}\right.$ and $\mathrm{MJ} \mathrm{m}^{-3}$, respectively); $\mathrm{FVI}=$ fuel value index [(net calorific value $\left.\mathrm{x} \mathrm{BDen}\right) /$ (MC x Ash)]

${ }^{\mathrm{b}} P=$ probability of $F$ for testing species: $* * * P<0.001$; ** $P<0.01$; numerator/denominator degrees of freedom $=4 / 344$

${ }^{\mathrm{c}}$ Species: Ba Balanites aegyptiaca, Cg Combretum glutinosum, Gs Guiera senegalensis, Pr Piliostigma reticulatum, Zm Ziziphus mauritiana; least squares means with the same letter are not significantly different $(P>0.05)$ and those with different letters are significantly different $(P<0.05)$ based on Tukey HSD test; sample size $=78$ for $\mathrm{Ba}$ and 79 for other species

For example, FVI tended to be higher in the three easternmost regions (\#1, \#2,\#3) for B. aegyptiaca, but in an eastern and two western regions (\#1, \#4, \#5) for Z. mauritiana. These regional differences in FVI reflected the differences in Ash and MC. In addition, MC of C. glutinosum and $P$. reticulatum was generally lower in the eastern regions. Fuelwood properties of $G$. senegalensis were generally good in all regions (e.g., high GCV, low Ash).

3.3 Differences in fuelwood properties among soil, land use, and terrain types

Soil and land use types had significant effects on some fuelwood properties, but the effect of terrain type was not significant for any variable (Table 4). In the analysis among species, $\mathrm{MC}$ was greater on sandy and sandy/loam soils than on rocky soils. Since MC is in the denominator of FVI, FVI was greater on rocky and sandy/loam than on sandy soils. Analyses within species gave similar results for C. glutinosum (FVI), B. aegyptiaca, G. senegalensis, and Z. mauritiana (MC). The effect of land use was significant for $G$. senegalensis and Z. mauritiana: Ash of G. senegalensis was greater in parklands than in woodlands; while Vol of $Z$. mauritiana was greater and Carb was lower in parklands than in woodlands.

\section{Discussion}

\subsection{Differences in fuelwood properties among species}

There are only a few published reports about fuelwood properties of the five species included in this study. Values for GCV and BDen of B. aegyptiaca in this study were slightly lower than those reported for 13-year-old trees in a genetic evaluation test in Niger (Sotelo Montes et al. 2011). Values for BDen of B. aegyptiaca, C. glutinosum, G. senegalensis, and Z. mauritiana were similar to those observed among 5-14-year-old trees in natural populations in Burkina Faso, but BDen of $P$. reticulatum was higher in the Burkina Faso study (Nygård and Elving 2000). There are no other published reports about fuelwood properties of these species in the region. In India, young trees $(<4$ years $)$ of Z. mauritiana had lower GCV than the trees in this study (Puri et al. 1994).

Coefficients of variation for BDen, Vol, Carb, MC, GCV, and $\mathrm{GCVm}^{3}$ were very low in this study. This is consistent with studies of BDen in natural populations in Burkina Faso (Nygård and Elving 2000) and of BDen, GCV, and GCVm ${ }^{3}$ in genetic evaluation tests (e.g., Sotelo Montes et al. 2003; Sotelo Montes and Weber 2009; Weber and Sotelo Montes 2010; Sotelo Montes et al. 2011). The low coefficients of variation probably reflect the fact that most wood properties are under relatively strong genetic control (i.e., have higher heritability) and are less affected by environmental conditions than traits such as tree height and stem diameter (e.g., Sotelo Montes et al. 2006; Sotelo Montes and Weber 2009).

In contrast, the coefficients of variation for Ash and FVI were very large in this study. The large coefficient of variation for Ash suggests that it is more affected by local environmental conditions than the other fuelwood properties. Ash contains calcium and potassium (Ragland et al. 1991), and one would expect higher calcium and potassium contents in plant tissues growing on soils with greater 
Table 3 Means of fuelwood properties of five tree/shrub species in five regions in Mali
${ }^{\mathrm{a}}$ Species: Ba Balanites aegyptiaca, Cg Combretum glutinosum, Gs Guiera senegalensis, Pr Piliostigma reticulatum, Zm Ziziphus mauritiana

${ }^{\mathrm{b}}$ Variable: Vol, Carb, Ash, and $\mathrm{MC}=$ volatile matter, fixed carbon, ash, and moisture, respectively, of wood (\%); GCV and $\mathrm{GCVm}^{3}=$ gross calorific value of wood $\left(\mathrm{MJ} \mathrm{kg}^{-1}\right.$ and $\mathrm{MJ} \mathrm{m}^{-3}$, respectively); FVI=fuel value index [(net calorific value $\times \mathrm{BDen}) /(\mathrm{MC} \times \mathrm{Ash})]$

${ }^{\mathrm{c}} P=$ probability of $\mathrm{F}$ for testing regions: $* * * P<0.001$,

$* * P<0.01, * P<0.05$, ns $P>0.05$; numerator/denominator degrees of freedom $=4 / 74$

${ }^{\mathrm{d}} \mathrm{R} 1$ to $\mathrm{R} 5=$ regions 1 to 5 (see Fig. 1); least squares means with the same letter are not significantly different $(P>0.05)$ and those with different letters are significantly different $(P<0.05)$ based on Tukey HSD test; sample size $=78$ for $\mathrm{Ba}$ and 79 for other species

\begin{tabular}{|c|c|c|c|c|c|c|c|}
\hline \multirow[t]{2}{*}{ Species $^{\mathrm{a}}$} & \multirow[t]{2}{*}{ Variable $^{\mathrm{b}}$} & \multirow[t]{2}{*}{$P^{\mathrm{c}}$} & \multicolumn{5}{|c|}{ Means for regions ${ }^{\mathrm{d}}$} \\
\hline & & & $\mathrm{R} 1$ & $\mathrm{R} 2$ & $\mathrm{R} 3$ & $\mathrm{R} 4$ & $\mathrm{R} 5$ \\
\hline $\mathrm{Ba}$ & BDen & ns & $605 a$ & $632 \mathrm{a}$ & $613 a$ & $610 \mathrm{a}$ & $616 a$ \\
\hline $\mathrm{Ba}$ & Vol & $* *$ & $80.48 b$ & $80.48 b$ & $80.47 b$ & $80.49 b$ & $79.07 \mathrm{a}$ \\
\hline $\mathrm{Ba}$ & Carb & $*$ & $18.25 \mathrm{a}$ & $18.48 \mathrm{ab}$ & $18.41 \mathrm{ab}$ & $18.26 \mathrm{a}$ & $19.37 \mathrm{~b}$ \\
\hline $\mathrm{Ba}$ & Ash & $* * *$ & $1.28 \mathrm{ab}$ & $1.04 \mathrm{a}$ & $1.12 \mathrm{a}$ & $1.25 \mathrm{ab}$ & $1.56 \mathrm{~b}$ \\
\hline $\mathrm{Ba}$ & $\mathrm{MC}$ & $* * *$ & $10.35 \mathrm{a}$ & $9.94 \mathrm{a}$ & $10.48 \mathrm{a}$ & $12.19 \mathrm{~b}$ & $12.74 b$ \\
\hline $\mathrm{Ba}$ & $\mathrm{GCV}$ & $*$ & $18.85 \mathrm{a}$ & $19.22 \mathrm{ab}$ & $19.25 \mathrm{ab}$ & $19.02 \mathrm{ab}$ & $19.36 \mathrm{~b}$ \\
\hline $\mathrm{Ba}$ & $\mathrm{GCVm}^{3}$ & ns & $11,413 \mathrm{a}$ & $12,149 \mathrm{a}$ & $11,814 \mathrm{a}$ & $11,611 \mathrm{a}$ & $11,928 \mathrm{a}$ \\
\hline $\mathrm{Ba}$ & FVI & $* * *$ & $953 b c$ & $1139 \mathrm{c}$ & $1010 \mathrm{bc}$ & $749 \mathrm{ab}$ & $577 \mathrm{a}$ \\
\hline $\mathrm{Cg}$ & BDen & ns & $691 \mathrm{a}$ & $681 \mathrm{a}$ & $655 a$ & $655 \mathrm{a}$ & $651 \mathrm{a}$ \\
\hline $\mathrm{Cg}$ & Vol & ns & $80.75 a$ & $79.65 a$ & $79.61 \mathrm{a}$ & $79.99 \mathrm{a}$ & $79.73 a$ \\
\hline $\mathrm{Cg}$ & Carb & ns & $17.89 \mathrm{a}$ & $19.11 \mathrm{a}$ & $19.34 \mathrm{a}$ & $18.81 \mathrm{a}$ & $19.06 \mathrm{a}$ \\
\hline $\mathrm{Cg}$ & Ash & ns & $1.37 \mathrm{a}$ & $1.25 \mathrm{a}$ & $1.06 \mathrm{a}$ & $1.21 \mathrm{a}$ & $1.22 \mathrm{a}$ \\
\hline $\mathrm{Cg}$ & $\mathrm{MC}$ & $* * *$ & $9.85 \mathrm{a}$ & $9.77 \mathrm{a}$ & $10.20 \mathrm{a}$ & $11.76 \mathrm{~b}$ & $12.30 \mathrm{~b}$ \\
\hline $\mathrm{Cg}$ & GCV & ns & $18.96 a$ & $19.09 \mathrm{a}$ & $19.13 \mathrm{a}$ & $19.17 \mathrm{a}$ & $19.05 \mathrm{a}$ \\
\hline $\mathrm{Cg}$ & $\mathrm{GCVm}^{3}$ & ns & $13,095 \mathrm{a}$ & $13,001 \mathrm{a}$ & $12,519 a$ & $12,547 \mathrm{a}$ & $12,373 a$ \\
\hline $\mathrm{Cg}$ & FVI & $\mathrm{ns}$ & $1,110 \mathrm{a}$ & $1,091 \mathrm{a}$ & $1,199 \mathrm{a}$ & $866 a$ & $833 a$ \\
\hline Gs & BDen & $\mathrm{ns}$ & $685 a$ & $679 a$ & $676 a$ & $658 \mathrm{a}$ & $666 a$ \\
\hline Gs & Vol & $*$ & $80.27 b$ & 79.96ab & $79.33 \mathrm{a}$ & $80.15 \mathrm{ab}$ & $79.80 \mathrm{ab}$ \\
\hline Gs & Carb & $* *$ & $19.06 \mathrm{a}$ & $19.50 \mathrm{ab}$ & $20.06 b$ & 19.22ab & $19.50 \mathrm{ab}$ \\
\hline Gs & Ash & ns & $0.68 \mathrm{a}$ & $0.54 \mathrm{a}$ & $0.62 \mathrm{a}$ & $0.64 \mathrm{a}$ & $0.71 \mathrm{a}$ \\
\hline Gs & $\mathrm{MC}$ & $* * *$ & $10.25 \mathrm{a}$ & $12.58 \mathrm{~b}$ & $10.51 \mathrm{a}$ & $11.67 \mathrm{ab}$ & $10.92 \mathrm{a}$ \\
\hline Gs & $\mathrm{GCV}$ & $*$ & $19.97 \mathrm{ab}$ & $19.87 \mathrm{ab}$ & $20.12 b$ & 19.91ab & $19.78 \mathrm{a}$ \\
\hline GS & $\mathrm{GCVm}^{3}$ & $\mathrm{~ns}$ & $13,681 \mathrm{a}$ & $13,501 \mathrm{a}$ & $13,608 \mathrm{a}$ & $13,108 \mathrm{a}$ & $13,180 \mathrm{a}$ \\
\hline Gs & FVI & $\mathrm{ns}$ & $1,991 \mathrm{a}$ & $2,340 \mathrm{a}$ & $2,266 \mathrm{a}$ & $1,959 \mathrm{a}$ & $1,847 \mathrm{a}$ \\
\hline $\operatorname{Pr}$ & BDen & $\mathrm{ns}$ & $537 \mathrm{a}$ & $547 \mathrm{a}$ & $533 a$ & $504 a$ & $528 \mathrm{a}$ \\
\hline $\operatorname{Pr}$ & Vol & $* *$ & $79.29 b$ & $79.28 b$ & $78.23 \mathrm{ab}$ & 78.00ab & $77.44 \mathrm{a}$ \\
\hline $\operatorname{Pr}$ & Carb & $* *$ & $18.86 a$ & $18.98 \mathrm{ab}$ & $20.03 c$ & $20.02 b c$ & $20.27 \mathrm{c}$ \\
\hline $\operatorname{Pr}$ & Ash & $\mathrm{ns}$ & $1.86 a$ & $1.74 \mathrm{a}$ & $1.75 \mathrm{a}$ & $1.98 \mathrm{a}$ & $2.30 \mathrm{a}$ \\
\hline $\operatorname{Pr}$ & $\mathrm{MC}$ & $* * *$ & $10.81 \mathrm{a}$ & 11.44ab & $12.65 \mathrm{c}$ & $12.51 b c$ & $11.32 \mathrm{a}$ \\
\hline $\operatorname{Pr}$ & GCV & * & $19.13 b$ & 19.09ab & 19.06ab & $19.11 \mathrm{ab}$ & $18.74 \mathrm{a}$ \\
\hline $\mathrm{Pr}$ & $\mathrm{GCVm}^{3}$ & ns & $10,266 a$ & $10,440 \mathrm{a}$ & $10,157 \mathrm{a}$ & $9,626 a$ & $9,889 \mathrm{a}$ \\
\hline $\operatorname{Pr}$ & FVI & $\mathrm{ns}$ & $544 \mathrm{a}$ & $566 a$ & $472 \mathrm{a}$ & $403 a$ & $399 a$ \\
\hline $\mathrm{Zm}$ & BDen & $\mathrm{ns}$ & $583 a$ & $567 \mathrm{a}$ & $558 \mathrm{a}$ & $560 \mathrm{a}$ & $576 a$ \\
\hline $\mathrm{Zm}$ & Vol & $* * *$ & $80.71 \mathrm{ab}$ & $80.84 b$ & $79.54 \mathrm{a}$ & $81.36 \mathrm{~b}$ & $81.05 b$ \\
\hline $\mathrm{Zm}$ & Carb & $* * *$ & $18.08 \mathrm{a}$ & $17.79 \mathrm{a}$ & $19.34 b$ & $17.72 \mathrm{a}$ & $17.97 \mathrm{a}$ \\
\hline $\mathrm{Zm}$ & Ash & $*$ & $1.21 \mathrm{ab}$ & $1.37 \mathrm{~b}$ & $1.12 \mathrm{ab}$ & $0.92 \mathrm{a}$ & $0.98 \mathrm{ab}$ \\
\hline $\mathrm{Zm}$ & $\mathrm{MC}$ & $* * *$ & $10.05 \mathrm{a}$ & $11.26 \mathrm{bc}$ & $12.03 \mathrm{c}$ & $10.67 \mathrm{ab}$ & $10.01 \mathrm{a}$ \\
\hline $\mathrm{Zm}$ & GCV & $*$ & $19.28 \mathrm{a}$ & $19.52 \mathrm{a}$ & $19.20 \mathrm{a}$ & $19.53 \mathrm{a}$ & $19.47 \mathrm{a}$ \\
\hline $\mathrm{Zm}$ & $\mathrm{GCVm}^{3}$ & $\mathrm{~ns}$ & $11,224 \mathrm{a}$ & $11,070 \mathrm{a}$ & $10,721 \mathrm{a}$ & $10,938 \mathrm{a}$ & $11,227 \mathrm{a}$ \\
\hline $\mathrm{Zm}$ & FVI & $* *$ & $977 \mathrm{ab}$ & $698 \mathrm{a}$ & $785 \mathrm{ab}$ & $1063 b$ & $1067 b$ \\
\hline
\end{tabular}

available calcium and potassium (Sarmiento et al. 1985). The availability of these minerals is affected by many factors such as the bedrock type; soil type, organic matter content, and $\mathrm{pH}$; intensity of rainfall and leaching; landuse history (e.g., number of years under cultivation and fallow, crop species grown) and farmers' soil improvement practices in the parklands (e.g., cutting and burning shrubs, and applying manure before sowing crops); the specific microhabitat created by the tree and neighboring trees; and the amount of potassium- and calcium-rich dust that is transported from the Sahara Desert by the Harmattan winds and deposited on tree leaves and soil during the dry season 
Table 4 Means of fuelwood properties of five tree/shrub species in different soil and land use types in Mali ${ }^{\mathrm{a}}$

\begin{tabular}{|c|c|c|c|c|c|}
\hline Species ${ }^{\mathrm{b}}$ & Variable $^{c}$ & $\mathrm{P}^{\mathrm{d}}$ & \multicolumn{3}{|c|}{ Means for land use and soil types } \\
\hline & & & \multicolumn{3}{|l|}{ Soil type } \\
\hline & & & Sandy & Sand/Loam & Rocky \\
\hline All & $\mathrm{MC}$ & $* * *$ & $11.41 \mathrm{~b}$ & $11.13 \mathrm{ab}$ & $10.85 \mathrm{a}$ \\
\hline All & FVI & $*$ & $997 \mathrm{a}$ & $1065 \mathrm{ab}$ & $1167 b$ \\
\hline $\mathrm{Ba}$ & $\mathrm{MC}$ & $* *$ & $11.51 \mathrm{~b}$ & $10.92 \mathrm{a}$ & $10.99 \mathrm{a}$ \\
\hline $\mathrm{Cg}$ & FVI & $* *$ & $929 a b$ & $870 \mathrm{a}$ & $1261 b$ \\
\hline Gs & $\mathrm{MC}$ & $*$ & $11.67 \mathrm{~b}$ & $11.02 \mathrm{ab}$ & $10.86 \mathrm{a}$ \\
\hline \multirow[t]{3}{*}{$\mathrm{Zm}$} & $\mathrm{MC}$ & $*$ & $11.17 \mathrm{~b}$ & $10.90 \mathrm{ab}$ & $10.34 \mathrm{a}$ \\
\hline & & & \multicolumn{3}{|c|}{ Land use type } \\
\hline & & & Parkland & \multicolumn{2}{|l|}{ Woodland } \\
\hline Gs & Ash & $* *$ & $0.74 \mathrm{~b}$ & \multicolumn{2}{|l|}{$0.54 \mathrm{a}$} \\
\hline $\mathrm{Zm}$ & Vol & $* *$ & $81.22 \mathrm{~b}$ & \multicolumn{2}{|l|}{$80.18 \mathrm{a}$} \\
\hline $\mathrm{Zm}$ & Carb & $*$ & $17.76 \mathrm{a}$ & \multicolumn{2}{|l|}{$18.60 \mathrm{~b}$} \\
\hline
\end{tabular}

${ }^{a}$ Results shown only for variables with significant difference among soil or land use types

${ }^{\mathrm{b}}$ Species: All all species; Ba Balanites aegyptiaca, Cg Combretum glutinosum, Gs Guiera senegalensis, Pr Piliostigma reticulatum, Zm Ziziphus mauritiana

${ }^{\mathrm{c}}$ Variable: Vol, Carb, Ash, and MC=volatile matter, fixed carbon, ash, and moisture, respectively, of wood (\%); FVI=fuel value index [(net calorific value $\times \mathrm{BDen}) /(\mathrm{MC} \times \mathrm{Ash})]$

${ }^{\mathrm{d}} P=$ probability of $\mathrm{F}$ for testing means: $* * * P<0.001, * * P<0.01, * P<$ 0.05 ; numerator/denominator degrees of freedom $=2 / 344$ for all species, 2/75 (Ba) or 2/76 (other species) for soil type and 1/77 for land use type

${ }^{\mathrm{e}}$ Least squares means with the same letter are not significantly different $(P>0.05)$ and those with different letters are significantly different $(P<0.05)$ based on Tukey HSD test; sample size $=78$ for $\mathrm{Ba}$ and 79 for other species

(Wezel et al. 2000). Therefore, one would expect considerable spatial variability in available soil calcium and potassium and, as a result, considerable variability in ash content among trees. The large coefficient of variation for FVI reflects the fact that it was derived from four variables (BDen, Net CV, MC, Ash), so the coefficient of variation reflects the combined variation/covariation among these variables.

\subsection{Differences in fuelwood properties among regions}

Regional differences were significant for the majority of the fuelwood properties of $B$. aegyptiaca, $G$ senegalensis, $P$. reticulatum, and $Z$. mauritiana. This reflects in part the fact that several variables were highly correlated (Sotelo Montes et al., unpublished data) due to the way they were measured or derived. Vol and Ash were measured and percent Carb was calculated as the difference: as a result, Vol was negatively correlated with Carb and Ash (mean Pearson $r$ of five species $=-0.95$ and -0.39 , respectively, $P<0.001, N=79$ for each species). In addition, $\mathrm{GCVm}^{3}$ and FVI were correlated with the variables used to derive them. Therefore, if one variable differs significantly among regions and it is strongly correlated with a second variable, then the second variable also differs significantly among regions.

In contrast to the other species, most fuelwood properties of C. glutinosum did not differ significantly among regions. This indicates that the variation among $C$. glutinosum trees within regions was considerably greater than the differences among regions, compared with the other species. This is consistent with the fact that the coefficients of variation for fuelwood properties were generally greater for $C$. glutinosum than for the other species, and suggests that local environmental conditions may have a relatively greater effect on fuelwood properties of $C$. glutinosum trees, compared with the other species.

BDen did not differ significantly among regions for any species in this study, also indicating that the variation within regions was considerably greater than the differences among regions. Small differences in BDen were also observed among natural populations of B. aegyptiaca, C. glutinosum, and G. senegalensis in Burkina Faso (Nygård and Elving 2000), and results from provenance/progeny tests generally show that there is more variation in BDen within populations than among populations (e.g., Sotelo Montes and Weber 2009; Weber and Sotelo Montes 2010).

Mean annual rainfall differed among regions (Table 1) so one might expect that the regional differences in fuelwood properties were due, at least in part, to the regional differences in rainfall (Sotelo Montes et al. 2011). The effect of rainfall on fuelwood properties of the five species was investigated (Sotelo Montes et al., unpublished data): in most cases, regressions of fuelwood properties with rainfall were not significant or they explained very little variation. Therefore, other variables in addition to rainfall are important in explaining the regional differences in fuelwood properties.

4.3 Differences in fuelwood properties among soil, land use, and terrain types

Soil type had a general effect on wood MC and FVI of the five species. MC tended to be higher on sandy soils and lower on rocky soils and, since MC and FVI are inversely related, FVI tended to be higher on rocky soils. This suggests that fuelwood production for these species should be promoted primarily on rocky soils in the study region.

Ash of G. senegalensis and Vol of Z. mauritiana was greater in parklands than in woodlands. In terms of fuelwood production, these results suggest that woodlands would be better for G. senegalensis (lower Ash), but parklands would be better for $Z$. mauritiana (higher Vol, which is positively correlated with FVI: Pearson $r=0.45, P<0.001$, $N=79$ ). Ash is composed primarily of calcium and potassium (Ragland et al. 1991), and the concentration of these 
minerals in plant tissues is generally higher in more fertile soils (Sarmiento et al. 1985). Farmers' management practices, such as burning brush and applying organic fertilizer before sowing crops, should increase soil fertility in parklands over time, so the higher Ash of G. senegalensis wood in parklands may reflect the more fertile soils. The higher Vol content of $Z$. mauritiana wood in parklands may be due to the production of protective compounds. In theory, one would expect greater production of resins and other protective compounds in the wood in locations with larger populations of wood-boring insects (Zangerl and Bazzaz 1992).

4.4 Recommendations for fuelwood production in the study regions

Based on the results of this study and other considerations, we recommend the following:

- Promote fuelwood production of $G$. senegalensis throughout the study region, B. aegyptiaca and C. glutinosum in the drier eastern regions, and Z. mauritiana in the more humid western regions.

- Promote fuelwood production of these species on sites with rocky, less fertile soils in the study region because the wood's moisture content was lower on rocky soils, and one would expect that the wood's ash content would be lower on less fertile soils. In general, this means targeting sites not considered priority for crop production.

- Conduct research to identify the specific environmental conditions that affect fuelwood properties of these species. This is particularly important for C. glutinosum, since local environmental conditions may have a relatively greater effect on fuelwood properties of this species, compared with the other species.

- Collect seed of the recommended species in the driest locations for establishing fuelwood plantations. This is based on climate change models that predict higher temperatures coupled with lower and more variable rainfall in the study region (Buontempo 2010), and the expectation that progeny of trees from drier locations are better adapted to drought (e.g. Sotelo Montes et al. 2011).

Acknowledgments Special thanks to the team in the Laboratory of Energy of Biomass (LEB) at Universidade Federal do Paraná (UFPR: Fernanda Marchiori, Rodrigo Medeiros Ribeiro, Sandra Lucia Soares Mayera), the International Crops Research Institute for the Semi Arid Tropics (ICRISAT) for providing laboratory facilities in Mali, Jane Poole for statistical advice, and the anonymous reviewers for their useful comments on an earlier version of this manuscript.

Funding This research was supported by a post-doctoral research grant from the World Agroforestry Centre (ICRAF) to the first author, and funds from the International Fund for Agricultural Development (IFAD) and the Universidade Federal do Paraná (UFPR).

\section{References}

ABNT (1984) Determinação do poder calorífico superior da madeira e do carvão vegetal. Norma NBR 8633. Associação Brasileira de Normas Técnicas, Rio de Janeiro

ABNT (1986) Carvão vegetal—análise imediata. Norma NBR 8112. Associacão Brasileira de Normas Técnicas, Rio de Janeiro

ASTM (1997) Standard test methods for specific gravity of wood and wood-base materials. ASTM D2395-93. In: Annual Book of ASTM Standards 4.10, American Society for Testing and Materials, Philadelphia, pp 348-355

Berger A, Grouzis M, Fournier C (1996) The water status of six woody species coexisting in the Sahel (Ferlo, Senegal). J Trop Ecol $12: 607-627$

Buontempo C (2010) Sahelian climate: past, current, projections. Met Office Hadley Centre, Devon

Clifford SC, Arndt SK, Corlett JE, Joshi S, Sankha N, Popp M, Jones HG (1998) The role of solute accumulation, osmotic adjustment and changes in cell wall elasticity in drought tolerance in Ziziphus mauritiana Lamk. J Exp Bot 49:967-977

FAO (2011) State of the world's forests. Food and Agriculture Organization of the United Nations, Rome

Faye MD, Weber JC, Abasse TA, Boureima M, Larwanou M, Bationo AB, Diallo BO, Sigué H, Dakouo J-M, Samaké O, Sonogo Diaité D (2011) Farmers' preferences for tree functions and species in the West African Sahel. Trees Livelihoods 20:113-136

Fuwape JA, Akindele SO (1997) Biomass yield and energy value of some fast-growing multipurpose trees in Nigeria. Biomass Bioenergy 12:101-106

Gebrekirstos A, Mitlöhner R, Teketay D, Worbes M (2008) Climategrowth relationships of the dominant tree species from semi-arid savanna woodland in Ethiopia. Trees 22:631-641

Gourlay ID (1995) The definition of seasonal growth zone in some African acacia species - a review. IAWA J 16:353-359

Hall JB, Walker DH (1991) Balanites aegyptiaca a monograph. University of Wales School of Agricultural and Forest Science, Bangor

Hiernaux P, Le Houérou HN (2006) Les parcours du Sahel. Sécheresse 17:51-71

Hijmans RJ, Cameron SE, Parra JL, Jones PJ, Jarvis A (2005) Very high resolution interpolated climate surfaces for global land areas. Int J Climatol 25:1965-1978

Kataki R, Konwer D (2002) Fuelwood characteristics of some indigenous tree species of north-east India. Biomass Bioenergy 22:433-437

Kizito F, Dragila M, Sène M, Lufafa A, Diedhiou I, Dick RP, Selker JS, Dossa E, Khouma M, Badiane A, Ndiaye S (2006) Seasonal soil water variation and root patterns between two semi-arid shrubs coexisting with Pearl Millet in Senegal, West Africa. J Arid Environ 67:436-455

Kumar R, Pandey KK, Chandrashekar N, Mohan S (2010) Effect of tree-age on calorific value and other fuel properties of Eucalyptus hybrid. J For Res 21:514-516

Le Houérou HN (1980) The role of browse in the Sahelian and Sudanian zones. http://www.ilri.org/InfoServ/Webpub/fulldocs/ BROWSE_IN_AFRICA/Chapter6.htm

Lemenih M, Bekele T (2004) Effect of age on calorific value and some mechanical properties of three Eucalyptus species grown in Ethiopia. Biomass Bioenergy 27:223-232

McKendry P (2002) Energy production from biomass (part 1): overview of biomass. Bioresour Technol 83:37-46

Nirmal Kumar JI, Patel K, Kumar RN, Kumar Bhoi R (2011) An evaluation of fuelwood properties of some Aravally mountain tree and shrub species of Western India. Biomass Bioenergy 35:411414 
Nygård R, Elving B (2000) Stem basic density and bark proportion of 45 woody species in young savanna coppice forests in Burkina Faso. Ann For Sci 57:143-153

Puri S, Singh S, Bhushan B (1994) Evaluation of fuelwood quality of indigenous and exotic tree species of India's semiarid region. Agrofor Syst 26:123-130

Ragland KW, Aerts DJ, Baker AJ (1991) Properties of wood for combusion analysis. Bioresour Technol 37:161-168

Sarmiento G, Goldstein G, Meinzer F (1985) Adaptive strategies of woody species in neotropical savannas. Biol Rev 60:315-355

SAS Institute Inc (2004) SAS/STAT users' guide, version 9.1. SAS Institute Inc, Cary

Seghieri J, Simier M, Mahamane A, Hiernaux P, Rambal S (2005) Adaptive above-ground biomass, stand density and leaf water potential to droughts and clearing in Guiera senegalensis, a dominant shrub in Sahelian fallows (Niger). J Trop Ecol 21:203-213

Shanavas A, Mohan Kumar B (2003) Fuelwood characteristics of tree species in homegardens of Kerala, India. Agrofor Syst 58:11-24

Sotelo Montes C, Weber JC (2009) Genetic variation in wood density and correlations with tree growth in Prosopis africana from Burkina Faso and Niger. Ann For Sci 66:713

Sotelo Montes C, Vidaurre H, Weber JC (2003) Variation in stemgrowth and branch-wood traits among provenances of Calyco- phyllum spruceanum Benth. from the Peruvian Amazon. New For 26:1-16

Sotelo Montes C, Hernández R, Beaulieu J, Weber JC (2006) Genetic variation and correlations between growth and wood density of Calycophyllum spruceanum Benth. at an early age in the Peruvian Amazon. Silvae Genet 55:217-228

Sotelo Montes C, Silva DA, Garcia RA, Muñiz GIB, Weber JC (2011) Calorific value of Prosopis africana and Balanites aegyptiaca wood: relationships with tree growth, wood density and rainfall gradients in the West African Sahel. Biomass Bioenergy 35:346353

Tarhule A, Hughes M (2002) Tree-ring research in semi-arid West Africa: meed and potential. Tree-Ring Res 58:31-36

Weber JC, Sotelo Montes C (2010) Correlations and clines in tree growth and wood density of Balanites aegyptiaca (L.) Delile provenances in Niger. New For 39:39-49

Wezel A, Rajot J-L, Herbrig C (2000) Influence of shrubs on soil characteristics and their function in Sahelian agro-ecosystems in semi-arid Niger. J Arid Environ 44:383-398

Zangerl AR, Bazzaz FA (1992) Theory and pattern in plant defense allocation. In: Fritz RS, Simms EL (eds) Plant resistance to herbivores and pathogens - ecology, evolution, and genetics. University of Chicago Press, Chicago, pp 363-391 